\title{
Induced sputum cell and fluid-phase indices of inflammation: comparison of treatment with dithiothreitol vs phosphate-buffered saline
}

\author{
A. Efthimiadis, M.M.M. Pizzichini, E. Pizzichini, J. Dolovich, F.E. Hargreave
}

\begin{abstract}
Induced sputum cell and fluid-phase indices of inflammation: comparison of treatment with dithiothreitol vs phosphate-buffered saline. A. Efthimiadis, M.M.M. Pizzichini, E. Pizzichini, J. Dolovich, F.E. Hargreave. (CERS Journals Ltd 1997.

ABSTRACT: Treatment of sputum with dithiothreitol (DTT) gives reliable measurements of cellular and fluid-phase markers of airway inflammation. We investigated the extent to which DTT treatment influences these measurements as compared with phosphate-buffered saline (PBS).

Hypertonic saline-induced sputum, collected from 20 asthmatic subjects, was examined within 2 h. All portions which looked more solid (less fluid) than saliva were collected from the expectorate. The selected sputum was then divided into two portions: one treated with one volume of DTT and one volume of PBS, the other with two volumes of PBS. The filtrates were assessed blind for total and differential cell count, viability, and fluid-phase eosinophil cationic protein (ECP), fibrinogen, interleukin (IL)-5 and IL-8.

Sputum treated with DTT compared with PBS had lower proportions of viable cells (median 66 versus $74 \% ; \mathrm{p}=0.003$ ). In contrast, DTT-treated sputum had higher total cell counts (median 8.8 vs $2.8 \times 10^{6} \mathrm{~mL}^{-1}$; $\mathbf{p}<0.001$ ) and levels of ECP (median 1340 vs $\left.584 \mathrm{mg} \cdot \mathrm{L}^{-1} ; \mathbf{p}<0.001\right)$ The measurements were similar with respect to the proportion of eosinophils, neutrophils, lymphocytes, macrophages, and fluidphase fibrinogen, IL-5 and IL-8.

We conclude that dithiothreitol disperses cells more effectively and that this might account for the higher levels of eosinophil cationic protein. Dithiothreitol may affect cell viability, but the changes are not relevant with respect to cell counts. Additionally, dithiothreitol does not seem to influence the other measurements performed. Eur Respir J 1997; 10: 1336-1340.
\end{abstract}

\begin{abstract}
Asthma Research Group, Depts of Medicine and Paediatrics, St. Joseph's Hospital and McMaster University, Hamilton, Ontario, Canada.
\end{abstract}

Correspondence: F.E. Hargreave

Firestone Regional Chest and Allergy Unit St. Joseph's Hospital

50 Charlton Avenue East

Hamilton

Ontario

L8N 4A6

Canada

Keywords: Airway inflammation asthma

dithiothreitol

induced sputum

Received: June 241996

Accepted after revision February 121997

Supported by grants from Astra Pharma Inc. and Boehringer Ingelheim (Canada) Ltd.
Sputum examination has become an important method of assessing airway inflammation directly and relatively noninvasively. Two major developments have motivated the recent interest in this method: the induction of sputum with an aerosol of hypertonic saline in asthmatics unable to produce it spontaneously [1]; and improvements in the method of sputum examination to produce reliable results [2-4]. The latter have included: the use of dithiothreitol (DTT) to disperse cells [5]; the examination of cells on cytospins [6]; the collection of supernatant for fluid-phase measurements $[4,6,7]$; and the evaluation of the necessary properties required by a method to be applied in research or clinical practice, such as repeatability, validity [4] and responsiveness [8-10].

In 1964, Cleland [11] identified DTT and its isomer dithioethreitol as agents with low redox potential, which could reduce and split glycoprotein disulphide bonds. Subsequently, SHAH and DYE [12] showed that this property allowed dispersion of sputum before the processing of smears and cultures to identify mycobacteria. However, these agents were not used to process sputum for inflammatory cell examination until 1978 [5]. Sputum treatment with DTT did not affect cell morphology [5], and exposure to DTT for up to $30 \mathrm{~min}$ did not affect differential cell counts [3]. However, these studies were uncontrolled [3], or used a negative control, and the effects of DTT on the fluid-phase markers were not examined.

We have, therefore, investigated the effect of sputum selected from the remainder of the expectorate [13] treated with DTT, as compared with phosphate-buffered saline (PBS), on the cell content and fluid-phase levels of eosinophil cationic protein (ECP), fibrinogen, interleukin (IL)5 and IL-8. Each sample of sputum was divided into two portions: one treated with four volumes of DTT followed by four volumes of PBS, and the other with eight volumes of PBS alone. The measurements in the filtrates were performed blind to sputum or subject characteristics.

\section{Methods}

\section{Subjects}

The study population comprised 20 asthmatic patients recruited from the Firestone Regional Chest and Allergy Clinic (table 1). Asthma was identified by episodic wheezing, chest tightness and dyspnoea, and either by: 
Table 1. - Characteristics of subjects

\begin{tabular}{|c|c|}
\hline Subjects $\mathrm{n}$ & 20 \\
\hline Gender male/female & $12 / 8$ \\
\hline Age yrs & $49(12-69)$ \\
\hline Smoking current/ex & $1 / 11$ \\
\hline Atopic* & 12 \\
\hline FEV 1 L & $2.5(1.1-4.1)$ \\
\hline$\%$ pred & $78.2(50.0-130.0)$ \\
\hline $\mathrm{PC}_{20} \mathrm{mg} \cdot \mathrm{mL}^{-1 \dagger}$ & $1.4(0.07-16)$ \\
\hline Steroids inhaled/oral ${ }^{\ddagger}$ & $15 / 4$ \\
\hline
\end{tabular}

Data are presented as absolute number or as mean, and range in parenthesis. *: atopic means one or more positive allergy skin-prick test; beclomethasone dipropionate or budesonide and oral was prednisolone. FEV1: forced expiratory volume in one second; $\%$ pred: percentage of predicted value; PC20: provocative concentration of methacholine causing a $20 \%$ fall in FEV 1 .

reversible airflow limitation (forced expiratory volume in one second $(\mathrm{FEV} 1)<70 \%$ predicted or previous best, which increased by $\geq 15 \%$ after $200 \mu \mathrm{g}$ of salbutamol) $(n=8)$; or by methacholine airway hyperresponsiveness (provocative concentration producing a 20\% fall in FEV1 $\left.(\mathrm{PC} 20)<8 \mathrm{mg} \cdot \mathrm{mL}^{-1}\right)$ if the FEV1 was $>70 \%$ pred $(\mathrm{n}=12)$. The study was approved by the Hospital Research Committee and all subjects gave written informed consent.

\section{Study design}

This was a cross-sectional study, where samples of induced sputum were divided into two portions and treated with either DTT followed by PBS or with PBS alone. The samples were processed simultaneously by two observers, with a high interobserver repeatability on sputum handling and counting [14]. Cells and fluid-phase measurements were performed blind on coded filtrates.

\section{Clinical methods}

Subjects were screened by means of a questionnaire, spirometry and a methacholine inhalation test (if the FEV1 was $>70 \%$ ). Spirometry was performed with a PK 131 Morgan Spiroflow dry rolling-seal spirometer (Roxon Medi-Tech, Rexdale, Ontario, Canada). Baseline measurements of slow vital capacity (VC) and FEV1 were made according to American Thoracic Society (ATS) criteria [15], and reference values were taken from CRAPO et al. [16]. Methacholine inhalation tests and allergy skin tests, with 19 common allergen extracts, were performed using standard procedures [17, 18].

Sputum induction was performed with an aerosol of hypertonic saline using a modification of the method of PIN et al. [1]. The aerosol was generated by a Fisoneb Ultrasonic nebulizer (Canadian Medical Products Ltd, Markham, Ontario, Canada) with an output of 0.87 $\mathrm{mL} \cdot \mathrm{min}^{-1}$ and particle size of $5.58 \mu \mathrm{m}$ aerodynamic mass median diameter. Increasing concentrations of saline (3, 4 and 5\%) were inhaled via a mouthpiece, without a valve or noseclips, for $7 \mathrm{~min}$. After each inhalation, a FEV1 value was measured for safety, the mouth was rinsed with water, water was swallowed, and the nose was blown to reduce contamination of the specimen with saliva and postnasal drip. An attempt was then made to cough sputum into a sterile container.
Sputum samples were examined as soon as possible within $2 \mathrm{~h}$, using the method described by PizzichinI et al. [4]. The expectorated specimen consisting of sputum and saliva was poured into a Petri dish, and all portions which looked more solid (less fluid) than saliva were carefully selected and divided into two portions of similar weights. They were clear or opaque and had little or no squamous epithelial cell contamination. Both portions were examined simultaneously by two observers. One portion was weighed and treated with a volume of DTT (diluted to $0.1 \%$ by the addition of distilled water (Sputolysin 10\%; Calbiochem Corp., San Diego, CA, USA)) equal to four times this weight (i.e. if the weight was $1 \mathrm{mg}, 4 \mathrm{~mL}$ of DTT was added). The treated sputum was rocked for 15 min to break up the mucus. A further four volumes of PBS was then added, and the rocking was continued for 5 min to slow down the action of the DTT. The final concentration of DTT in the fluid recovered was $0.05 \%$. The other portion was weighed and treated with eight volumes of PBS for $20 \mathrm{~min}$. Each mixture was filtered through a $48 \mu$ m nylon mesh (B\&SH Thompson, Mississauga, Ontario, Canada). A total cell count was obtained with a modified Neubauer counting chamber and cell viability was determined by trypan blue exclusion. Cytospins were prepared, treated with Wright's stain and a 400 nonsquamous cell differential cell count was performed. The remaining cell suspension was cytocentrifuged at $790 \times \mathrm{g}$ for $4 \mathrm{~min}$ and the supernatant was collected and stored at $-70^{\circ} \mathrm{C}$ for later assay of ECP, fibrinogen, IL-5 and IL-8. The concentrations of ECP $\left(\mu \mathrm{g} \cdot \mathrm{L}^{-1}\right), \mathrm{IL}-5\left(\mathrm{pg} \cdot \mathrm{mL}^{-1}\right)$, and IL-8 $\left(\mathrm{pg} \cdot \mathrm{mL}^{-1}\right)$ in the thawed supernatant were determined using a sensitive radioimmunoassay (RIA; Kabi Pharmacia Diagnostics $\mathrm{AB}$, Uppsala, Sweden) and fibrinogen $\left(\mathrm{ng} \cdot \mathrm{mL}^{-1}\right)$ was measured by a "sandwich" enzyme-linked immunosorbent assay (ELISA) using a rabbit anti-human fibrinogen antibody (Dako No. A080) [4].

\section{Statistical analysis}

Results are summarized as median and interquartile range. Data with non-normal distribution (total cell counts, eosinophils, lymphocytes, ECP, fibrinogen, IL-5 and IL8 ) were log-transformed before analysis. Differences between samples were assessed by paired t-test. Correlations were assessed by the Spearman rank correlation coefficient. The effect of DTT on the slopes of the curves for the correlations was compared using regression analysis, with the DTT treatment as a covariate. Significance was accepted at the level of $95 \%$.

\section{Results}

The DTT-treated portions were compared with the portions treated with PBS alone (figs. 1 and 2 and table 2 ). They had a higher total cell count and ECP levels, and lower cell viability. The absolute eosinophil counts correlated positively with levels of ECP in both portions, and the correlations were not influenced by the DTT treatment. The differential cell count of eosinophils, neutrophils, lymphocytes and macrophages and the levels of fluid-phase fibrinogen, IL-5 and IL-8 were not different (table 2). 

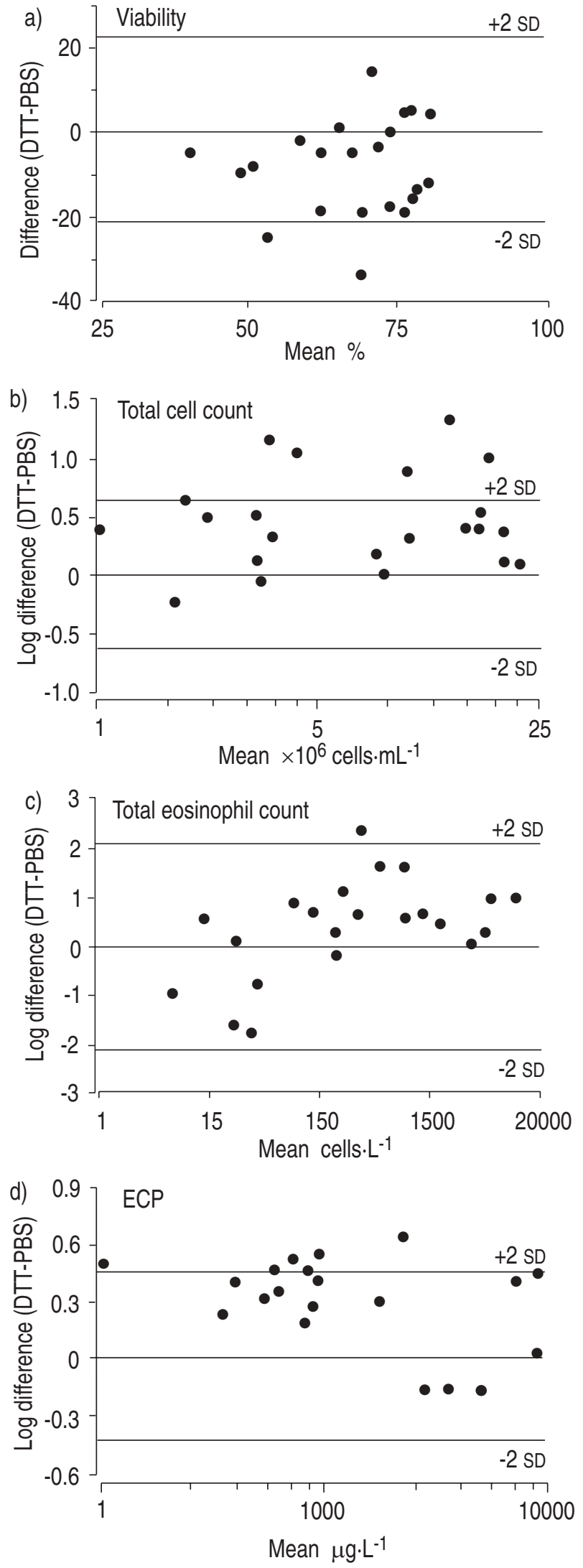

Fig. 1. - The difference (in logs, except for cell viability) between sputum treated with DTT and PBS on: a) cell viability; b) total cell count; c) absolute count of eosinophils; and d) ECP, plotted against the mean of the two values. DTT: dithiothreitol; PBS: phosphatebuffered saline; ECP: eosinophil cationic protein.
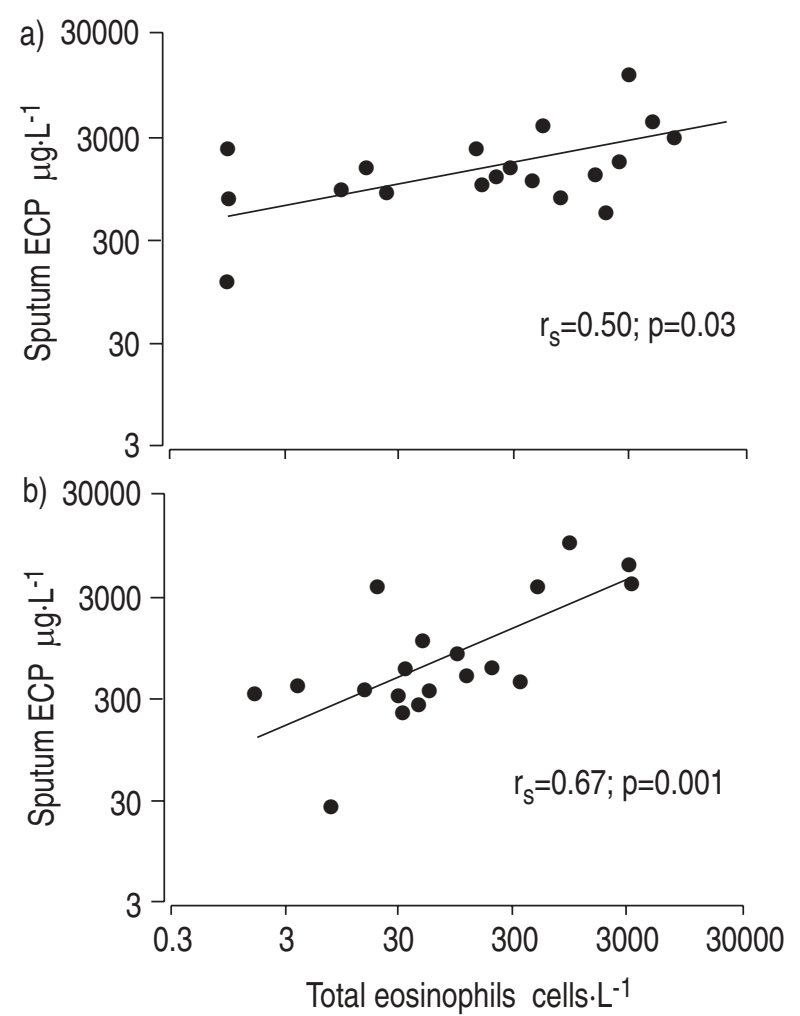

Fig. 2. - Correlations between absolute count of eosinophils in sputum and fluid-phase ECP in: a) DTT-treated and b) PBS-treated samples. $r_{s}$ : Spearman rank correlation coefficient. The solid line is the calculated linear regression. Highly significant correlations were observed in both portions of sputum between the absolute counts of eosinophils and ECP. For definitions see legend to figure 1.

Table 2. - Weight and values of inflammatory indices in sputum treated with DTT and PBS

\begin{tabular}{|c|c|c|c|c|}
\hline \multirow{2}{*}{ Weight mg } & \multicolumn{2}{|c|}{ DTT } & PBS & \multirow{2}{*}{$\frac{\text { p-value }}{\text { NS }}$} \\
\hline & 354 & $(183)$ & $(135)$ & \\
\hline $\begin{array}{l}\text { Total cell count } \\
\times 10^{6} \text { cells } \cdot \mathrm{mL}^{-1}\end{array}$ & 8.8 & (20) & $(6.7)$ & 0.001 \\
\hline Viability \% & & (21) & (19) & 0.003 \\
\hline Eosinophils \% & 6.2 & (20) & (12) & NS \\
\hline Neutrophils \% & 52.9 & (34) & 60.7 & NS \\
\hline Lymphocytes \% & 1.0 & (1) & 1.4 & NS \\
\hline Macrophages \% & 28.4 & (29) & $19.3 \quad(24)$ & NS \\
\hline ECP $\mu \mathrm{g} \cdot \mathrm{L}^{-1}$ & 1340 & (2665) & $584(3392)$ & 0.001 \\
\hline Fibrinogen $\mu \mathrm{g} \cdot \mathrm{L}^{-1}$ & $5920(1$ & 11720) & $3760 \quad(6220)$ & NS \\
\hline IL-5 ng $\cdot \mathrm{L}^{-1}$ & 464 & $(444)$ & $368 \quad(568)$ & NS \\
\hline IL-8 $\quad \mu \mathrm{g} \cdot \mathrm{L}^{-1}$ & 13600 & 95440) & $13600(20740)$ & NS \\
\hline
\end{tabular}

Data are presented as median and interquartile range in parenthesis. DTT: dithiothreital; PBS: phosphate-buffered saline; ECP: Eosinophil cationic protein; IL: interleukin; NS: nonsignificant.

\section{Discussion}

In this study, portions of sputum were selected from the remainder of the expectorate. We have previously shown that this selected portion is minimally contaminated with saliva, whilst the remainder of the expectorate is mainly saliva contaminated with some sputum [13]. The selected sputum, when treated with DTT, resulted in a threefold higher cell recovery and a twofold higher level of fluid phase ECP than selected sputum treated with PBS alone. Viable cells were obtained in 
both portions, but cell viability was lower in the DTTtreated samples. The differential cell count and fluidphase concentrations of fibrinogen, IL 5 and IL- 8 were similar. The results of this study confirm that DTT breaks up mucus and disperses the cells much more effectively than PBS, and suggest that treatment of sputum with DTT does not adversely affect the cell counts or the fluid-phase indices measured.

This is the first comparison of inflammatory cells and fluid-phase markers between induced sputum treated with DTT or PBS. The comparison is important, since current methods of sputum examination involve the use of DTT to disperse cells, and its effects on soluble markers have not been investigated. Our results on inflammatory cells confirm and extend the initial observations of Wooton and Dulfano [5]. They are also in keeping with a previous examination of the effects of the exposure time to DTT on sputum total and differential cell counts [3]. The exposure of sputum to $0.1 \%$ DTT for increasing periods of 10,20 and $30 \mathrm{~min}$ increased the yield of cells and improved the quality of cytospin preparations. The reason for the lower viability of cells in the DTT-treated samples is unknown. Because it does not affect cell morphology [19] or differential cell counts [20], it may be falsely elevated in the PBS-treated samples due to the low recovery of cells. Whatever the reason, this is not important for cell counts because the cell viability, although lower, was still good in the DTTtreated sputum.

We found no effect of DTT on fluid-phase fibrinogen, IL-5 and IL-8. This is useful information, since DTT, by breaking disulphide bonds [11], could result in falsely low readings of cytokines or other inflammatory proteins, such as ECP and fibrinogen. Our results indicate that these effects are not relevant, at least for the indices measured in the way DTT was used and neutralized.

The fluid-phase levels of ECP were higher in DTTtreated samples. This could be due to a higher recovery of ECP, which is separated into the airway mucus, or alternatively to the activation of eosinophils or release of ECP from eosinophils by DTT. The first possibility is supported by the results of this study, showing an equally good correlation, without evidence of outliers, between the absolute number of eosinophils and the ECP levels in the supernatant in sputum treated both with DTT or PBS. It is also supported by a previous study [13], in which sputum selected from the expectorate was compared to the remainder (composed mostly of saliva). Whilst there was a loss of less than one third of the sputum (nonsquamous) cells from the selected portion compared to the remainder, the selected portion had a sixfold higher fluid phase concentration of ECP, suggesting that most of the ECP is contained within the mucus and that DTT is needed to release it. Further investigation is required to investigate the possibility that DTT may activate eosinophils or otherwise release ECP from eosinophils.

Two methods to examine sputum for inflammatory indices have been used. In one, sputum is selected from saliva [13], whilst in the other the whole expectorate of sputum plus saliva is examined [7]. The results of this study are valid for the selection method which has been described and evaluated in more detail. In this method, the influence of other confounders has been investigated $[3,14,21,22]$, and the measurements have been shown to be highly reproducible [4]. This implies that the results of this study are actually due to the effect of sputum with DTT or PBS, and not to other confounders in the method.

In conclusion, treatment of all portions of induced sputum (selected from the remainder of the expectorate) with dithiothreitol $0.1 \%$ for 15 min followed by phosphate-buffered saline does not adversely affect cell counts or fluid-phase levels of eosinophil cationic protein, fibrinogen, interleukin-5 and interleukin- 8 of asthmatic subjects. However, it does lead to a higher recovery of cells and eosinophil cationic protein.

Acknowledgements: The authors wish to thank the subjects who volunteered to help with this study, S. Weston for helping with cell counts, S. Evans for performing the fluid-phase measurements and Pharmacia Diagnostics AB, Uppsala, Sweden for providing the ECP kits.

\section{References}

1. Pin I, Gibson PG, Kolendowicz R, et al. Use of induced sputum cell counts to investigate airway inflammation in asthma. Thorax 1992; 47: 25-29.

2. Gibson PG, Girgis-Gabardo A, Morris MM, et al. Cellular characteristics of sputum from patients with asthma and chronic bronchitis. Thorax 1989; 44: 693-699.

3. Popov T, Gottschalk R, Kolendowicz R, Dolovich J, Powers P, Hargreave FE. The evaluation of a cell dispersion method of sputum examination. Clin Exp Allergy 1994; 24: 778-783.

4. Pizzichini E, Pizzichini MMM, Efthimiadis A, et al. Indices of airway inflammation in induced sputum: reproducibility and validity of cell and fluid phase measurements. Am J Respir Crit Care Med 1996; 154: 308-317.

5. Wooton OJ, Dulfano MJ. Improved homogenization techniques for sputum cytology counts. Ann Allergy 1978; 41: 150-154.

6. Virchow JC Jr, Holscher U, Virchow C Sr. Sputum ECP levels correlate with parameters of airflow obstruction. Am Rev Respir Dis 1992; 146: 604-606.

7. Fahy JV, Liu J, Wong X, Boushey HA. Cellular and biochemical analysis of induced sputum from asthmatic and healthy individuals. Am Rev Respir Dis 1993; 147 : 1126-1131.

8. Pin I, Freitag AP, O'Byrne PM, et al. Changes in cellular profile of induced sputum after allergen-induced asthmatic response. Am Rev Respir Dis 1992; 145: 1265-1269.

9. Maestrelli P, Calcagni PG, Saetta M, et al. Sputum eosinophilia after responses induced by isocyanates in sensitized subjects. Clin Exp Allergy 1994; 24: 29-34.

10. Gibson PG, Hargreave FE, Girgis-Gabardo A, Morris M, Denburg JA, Dolovich J. Chronic cough with eosinophilic bronchitis: examination for variable airflow obstruction and response to corticosteroid. Clin Exp Allergy 1995; 25: 127-132.

11. Cleland WW. Dithiothreitol, a new protective reagent for SH groups. Biochemistry 1964; 3: 480-482.

12. Shah RR, Dye WE. Use of dithiothreitol to replace Nacetyl-L-cysteine for routine sputum digestion-decontamination for the culture of mycobacteria. Lancet 1965; i: 454 . 
13. Pizzichini E, Pizzichini MMM, Efthimiadis A, Hargreave FE, Dolovich J. Measurement of inflammatory indices in induced sputum: effects of selection of the sputum to minimize salivary contamination. Eur Respir J 1996; 9: 1174-1180.

14. Efthimiadis A, Pizzichini MMM, Pizzichini E, et al. The influence of cell viability and squamous cell contamination on the reliability of sputum differential cell counts. Am J Respir Crit Care Med 1995; 151: A384.

15. American Thoracic Society (Statement). Standardization of spirometry: 1987 update. Am Rev Respir Dis 1987; 136: $1285-1298$.

16. Crapo RO, Morris AH, Gardner RM. Reference spirometric values using techniques and equipment that meets ATS recommendations. Am Rev Respir Dis 1981; 123: 659-694.

17. Juniper EF, Cockcroft DW, Hargreave FE. Histamine and methacholine inhalation tests: a laboratory tidal breathing protocol. Lund, Sweden, Astra Draco AB, 1994.

18. Pepys J. Skin tests in diagnosis. In: Gell PGH, Coombs RRD, Lachman PJ, eds. Clinical Aspects of Immunology. 3rd Edn. Oxford, Blackwell Scientific Publications, 1975; pp. 55-80.

19. Tang C, Kung ITM. Homogenization of sputum with dithiothreitol for early diagnosis of pulmonary malignancies. Acta Cytologica 1993; 37: 689-693.

20. Efthimiadis A, Popov T, Kolendowicz R, Dolovich J, Hargreave FE. Increasing the yield of sputum cells for examination. Am J Respir Crit Care Med 1994; 149: A949.

21. Popov TA, Pizzichini MMM, Pizzichini E, et al. Some technical factors influencing the induction of sputum for cell analysis. Eur Respir J 1995; 8: 559-565.

22. Pizzichini MMM, Popov T, Efthimiadis A, et al. Spontaneous and induced sputum to measure indices of airway inflammation. Am J Respir Crit Care Med 1996; 154: 866-869. 